\title{
QUANTIFICATION OF SUNFLOWER MINOR COMPONENTS BY NEAR INFRARED SPECTROMETRY (NIR)
}

\author{
Gotor, A.A ${ }^{1}$, Berger, M. ${ }^{1}$, Farkas, E. ${ }^{1}$, Labalette, F. ${ }^{2}$, \\ Centis, S. ${ }^{2}$, Calmon, A. ${ }^{1 *}$ \\ ${ }^{1}$ E.S.A. Purpan, Laboratoire d'Agrophysiologie UMR INRA 1054, \\ 75 voie du TOEC, BP 57611, 31076 Toulouse, France \\ ${ }^{2}$ ONIDOL, 12 avenue George V, 75008 Paris, France \\ ${ }^{3}$ ASEDIS-SO, 39 chemin Virebent, 31200 Toulouse, France
}

Received: October 10, 2006

Accepted: May 15, 2007

\section{SUMMARY}

Both plant breeding programs and food industry need to develop rapid and low cost methods to characterize sunflower prior to allotment. Near infrared spectrometry (NIRS) is widely used to classify sunflower lots according to fatty acid content. This study proposes an extension of NIRS potential use concerning sunflower by tocopherol and phytosterol content quantifications. Approximately 800 samples of ground sunflower kernels were scanned by NIRS at $2 \mathrm{~nm}$ intervals from 400 to $2500 \mathrm{~nm}$. For each sample standard measurements of tocopherol and phytosterol contents were performed. Total tocopherol content was obtained by high performance liquid chromatography (HPLC) coupled with a fluorescence detector while total phytosterol content was assessed by gas chromatography (GC). For tocopherol, the calibration data set ranged from 190 to $1280 \mathrm{mg} \cdot \mathrm{kg}^{-1}$ oil (mean value around $615 \pm 165$ $\mathrm{mg} \cdot \mathrm{kg}^{-1}$ oil) whereas for phytosterol content, the calibration data set ranged from 125 to $765 \mathrm{mg} \cdot 100 \mathrm{~g}^{-1}$ oil (mean value of $334+75 \mathrm{mg} \cdot 100 \mathrm{~g}^{-1}$ oil). The NIRS calibration showed a relative good correlation $\left(\mathrm{R}^{2}=0.62\right)$ between predicted by NIRS and real values for total tocopherol content but a poor correlation for total phytosterol content $\left(\mathrm{R}^{2}=0.21\right)$. These results indicate that NIR spectrometry could be useful to classify high and low tocopherol containing lots despite possible improvement of calibration by inclusion of a larger number of data in tocopherols NIRS calibration. In contrast, the determination of phytosterol content by NIRS needs more investigations. In this study, only one mathematical calibration was tested and other mathematical methods are under investigations.

Key words: sunflower, minor components in oil, tocopherols, fytosterols, NIRS analysis

\footnotetext{
* Corresponding author: e-mail: anne.calmon@esa-purpan.fr
} 


\section{INTRODUCTION}

Sunflower is an important oilseed crop around the word. The most common sunflower oil use concerns the edible oil industry (e.g., salad oil, margarine...). Recently it has been realized that the high oleic type of sunflower is a suitable material for non food applications such as lubricants, biocarburants (Ballerini, 2006; De Caro and Cecutti, 2005). In addition, classic or oleic sunflower seeds are rich in micronutrients such as tocopherols and phytosterols exhibiting different health benefits (cardiovasculars diseases, ageing disorders...). Tocopherols (vitamin E) are fat-soluble compounds exhibiting antioxidant properties leading to protection against chronic diseases (Beardsell et al., 2002; Bramley et al., 2000). The sunflower tocopherol complex is known to contain predominantly $\alpha$-tocopherol form that represents the vitamin for humans. Furthermore tocopherols are the most important compounds having antioxidant activity in vivo by quenching active oxygen and peroxide radicals (Hofius and Sonnewald, 2003). On the other hand, phytosterols (plant sterols) have a chemical structure similar to human cholesterol (Dutta and Normen, 1998). According to their particular amphiphyl properties, phytosterols reduce the absorption of dietary cholesterol (Normen et al., 2000; Trautwein et al., 2003). Moreover phytosterols, especially $\beta$-sitosterol, exhibit other beneficial properties such as anti-inflammatory and antitumor activity (Ling and Jones, 1995).

Thus, sunflower breeding programs are not based only on the fatty acid profile of hybrids but also start to include other selection characteristics like minor components (tocopherols and phytosterols). To include such new characteristics breeders need larger analytical input. Nowadays, tocopherol content is mainly determined by high performance liquid chromatography (HPLC) whereas phytosterol content is determined by gas chromatography (GC). These two analytical methods are long, expensive, using hazardous chemicals and requiring high qualification. Therefore these methods are poorly adapted to industrial uses which require a rapid and a low cost method to make easier the screening of vegetal material. Near-infrared reflectance spectrometry (NIRS) is a rapid, low cost and simple analytical tool. Indeed, NIRS is the most common tool used in seed breeding programs, to determine fatty acid composition in sunflower seeds (Moschner and Biskupek-Korel, 2006; Pérez-Vich et al., 1998). This simple analytical tool allows breeders to accelerate selection programs in order to obtain varieties with a high oleic acid.

Taking into account the increasing interest of breeding program in minor components of sunflower oil as breeding characteristics, the aim of this study was to develop a NIRS calibration to predict tocopherol and phytosterol contents in milled sunflower seeds in order to make a rapid selection between high or low minor component contents. 


\section{MATERIALS AND METHOD}

\section{Samples}

A collection of approximately 800 sunflower seeds samples recovered from several cultivars (breeding lines and hybrids) over three growing years (2003, 2004 and 2005) and from different planting locations (in all parts of France and Chile) were used to establish the calibration. For each sample used in NIRS procedure at least two replicate of tocopherols and phytosterols determination were performed by classical methods (HPLC and GC, respectively). The mean of these two replicates was considered as reference value.

\section{Solvent extraction of lipids}

The analysis of the total oil content was performed by hexane extraction using a Soxhlet extractor apparatus. Fifty grams of achenes were ground and introduced in cartridges. The ground achenes were submitted to hexane extraction for 4 hours. Then, the solvent was removed from the extracts under low pressure evaporation. Lipid extracts were weighed and conserved at $-18^{\circ} \mathrm{C}$.

\section{Tocopherol determination}

The complete separation of all native tocopherols was achieved using a highperformance liquid chromatography (HPLC) (SpectraPhysics, Thermo Separation Products, USA) with a normal phase LiChrorosorb Si60 column $-250 \mathrm{~cm} \times 4 \mathrm{~mm} \times$ $5 \mu \mathrm{m}$ (CIL Cluzeau, France). The mobile phase was a mixture of hexane/isopropanol (99.7:0.3 v/v) at $1 \mathrm{ml} / \mathrm{min}$ flow rate. One gram of oil sample was diluted in $25 \mathrm{ml}$ of hexane and injected directly into the HPLC. Detection was performed with a fluorescence detector (excitation wavelength $=298 \mathrm{~nm}$ and emission wavelength $=344 \mathrm{~nm}$; Waters 2475 multi $\lambda$ ). Tocopherols were identified by comparison of retention times with respective standards (Tocopherol Kit; ChromaDex, USA). Total tocopherol content was calculated as the sum of $\alpha-, \beta-, \gamma$ - and $\delta$-tocopherol contents.

\section{Sterol determination}

The total and individual sterol content was analyzed by gas chromatography (GC) after saponification and preparation with trimethylsylil (TMS) esther derivatives. One $\mu$ l of the TMS solutions were injected into a fused silica capillary (ZB-5) column (Phenomenex, Paris, France) in a Fisons gas chromatograph (GC 8000 series MMFC 800 Multi-function controller, Italy) fitted with a flame ionization detector. Sterols were identified using the ratio obtained between betulin (Internal standard, Sigma-Aldrich, France) and sterol standards. 


\section{NIRS analysis}

A FOSS NIR System 6500 (Foss Analytical, Denmark) was used to collect spectra from the milled sunflower seed samples (around $30 \mathrm{~g}$ ) using small round cup with a quartz window. The reflectance values as $[\log (1 / \mathrm{R})]$ of each sample were measured from 400 to $2500 \mathrm{~nm}$ at $2 \mathrm{~nm}$ intervals. For each sample, a screening of 32 measures was carried out and compared with 32 measures of a ceramic reference. For tocopherol prediction, a 687 spectra database was used for the calibration set and for phytosterol prediction, a 281 spectra database was used.

\section{Statistical analysis}

Prediction equations were calculated with a modified partial least-squares regression (MPLS) model after 4 outlier elimination passes (WINISI 1.02 - Infrasoft International LLC). Previous mathematical treatment was applied on each spectrum: a standard normal variate and detrend (SNV/detrend) scatter correction, a first derivative transformation, a gap as well as a smoothing of four data points. The equation with the highest coefficient of determination $\left(R_{c}\right)$ and the lowest standard error (SE) in the calibration was use to predict the tocopherol and the phytosterol values of the validation set.

\section{RESULTS AND DISCUSSION}

\section{Determination of reference values}

Tocopherol content determination in sunflower oil by HPLC showed that $\alpha$ tocopherol was the major tocopherol and represented more than $95 \%$ of the total tocopherol content which corresponded to the sum of the 4 isomers $\alpha, \beta, \gamma$ and traces of $\delta$-tocopherol. The total tocopherol content observed in this study ranged from $190 \mathrm{~g} / \mathrm{kg}$ oil to $1187.9 \mathrm{~g} / \mathrm{kg}$ oil and this range was similar to the values reported by Nolasco et al. (2004).

The most abundant sterol content observed in all cultivars was $\beta$-sitosterol (around 60\%), followed by campesterol and stigmasterol. Other phytosterols like $\Delta^{7}$-campesterol, $\Delta^{5}$-avenasterol, $\Delta^{7}$-stigmasterol and $\Delta^{7}$-avenasterol were detected at very low levels. These seven sterols represented the total phytosterol content in sunflower oil tested. The total phytosterol content in this study ranged between $125 \mathrm{mg} /$ $100 \mathrm{~g}$ oil and $765 \mathrm{mg} / 100 \mathrm{~g}$ oil. These results were similar to the values reported by Vlahakis and Hazebroek (2000).

Calibration dataset presented large variations for the alpha and total tocopherol contents as shown in Table 1 whereas these variations were less important for the total phytosterols content in the sunflower oil sample tested. Such discrepancies could be explained by the number of samples (lower numbered than for tocopherols) and by the lower variability due to experiment or genotype concerning phytosterols (Vlahakis and Hazebroek, 2000; Ayerdi Gotor et al., 2006). Moreover, a 
normal distribution of tocopherol and phytosterol content values was observed (Figure 1).
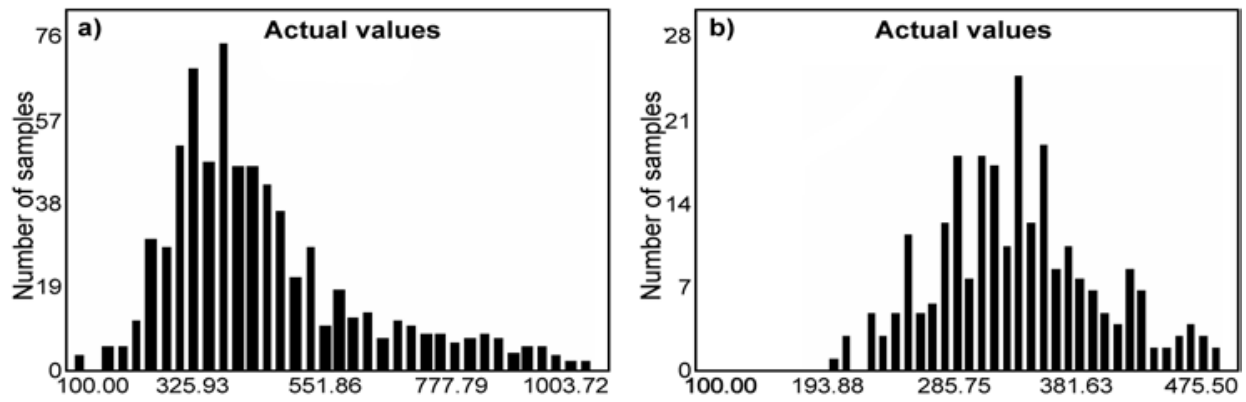

Figure 1: Histograms of (Tasinato et al.) total tocopherol content ( $\mathrm{mg} / \mathrm{kg}$ oil) and (b) total phytosterol ( $\mathrm{mg} / 100 \mathrm{~g}$ oil) used for the calibration equation

\section{NIRS calibration}

The reference values of all samples were used to make mathematical treatments in order to make the prediction equation with a modified PLS. The equations were used to calculate predicted values. The predictive values were given in Table 1 and the calibration graphics were shown in Figure 2.

Table 1: Formation of the calibration sets for the total tocopherol, $\alpha$-tocopherol and total phytosterol contents and calibration and cross calibration results for tocopherols and phytosterols predictions. (RSQ: coefficient of linear regression; SECV: standard error of cross validation; 1-VR: COEFFICIENT of determination in cross validation $\left(\mathrm{R}^{2}\right)$; SEC : standard error of calibration).

\begin{tabular}{llll}
\hline Parameters & \multicolumn{2}{l}{ Tocopherol $\left(\mathrm{mg} \cdot \mathrm{kg}^{-1}\right.$ oil) } & $\begin{array}{l}\text { Total phytosterol } \\
\left(\mathrm{mg} \cdot 100 \mathrm{~g}^{-1} \text { oil) }\right.\end{array}$ \\
\cline { 2 - 3 } & Alpha-T & Total-T & 282 \\
\hline Number of samples & 687 & 687 & $179.8-475.5$ \\
Range & $178.3-957.7$ & $197.1-1003.7$ & 318.46 \\
Mean & 489.70 & 462.10 & 80.85 \\
SD & 151.84 & 143.56 & 0.356 \\
RSQ & 0.735 & 0.727 & 54.823 \\
SECV & 91.150 & 94.182 & 0.207 \\
1- VR (R. & 0.620 & 0.619 & 48.964 \\
SEC & 74.658 & 80.093 &
\end{tabular}

The correlations between the predicted values and the reference values show that alpha and total tocopherol were better correlated $\left(\mathrm{R}^{2}=0.62\right)$ than phytosterols $\left(\mathrm{R}^{2}=0.21\right)$. For tocopherol the repartition of samples was homogeneous, contrary to the total phytosterol contents of all samples which were localized around the mean value.

The ratio (SD/SECV) for all minor components ranged from 1.5 to 1.7 . However, these values were quite different from 3 , which is considered as the minimal value for this ratio in good NIRS calibrations for agricultural raw materials in the 
literature (Moschner and Biskupek-Korell, 2006). Nevertheless, considering that the total tocopherol content or sterol content in sunflower seed is lower than $1 \%$ of the composition, these results are promising for possible improvement of the procedure.

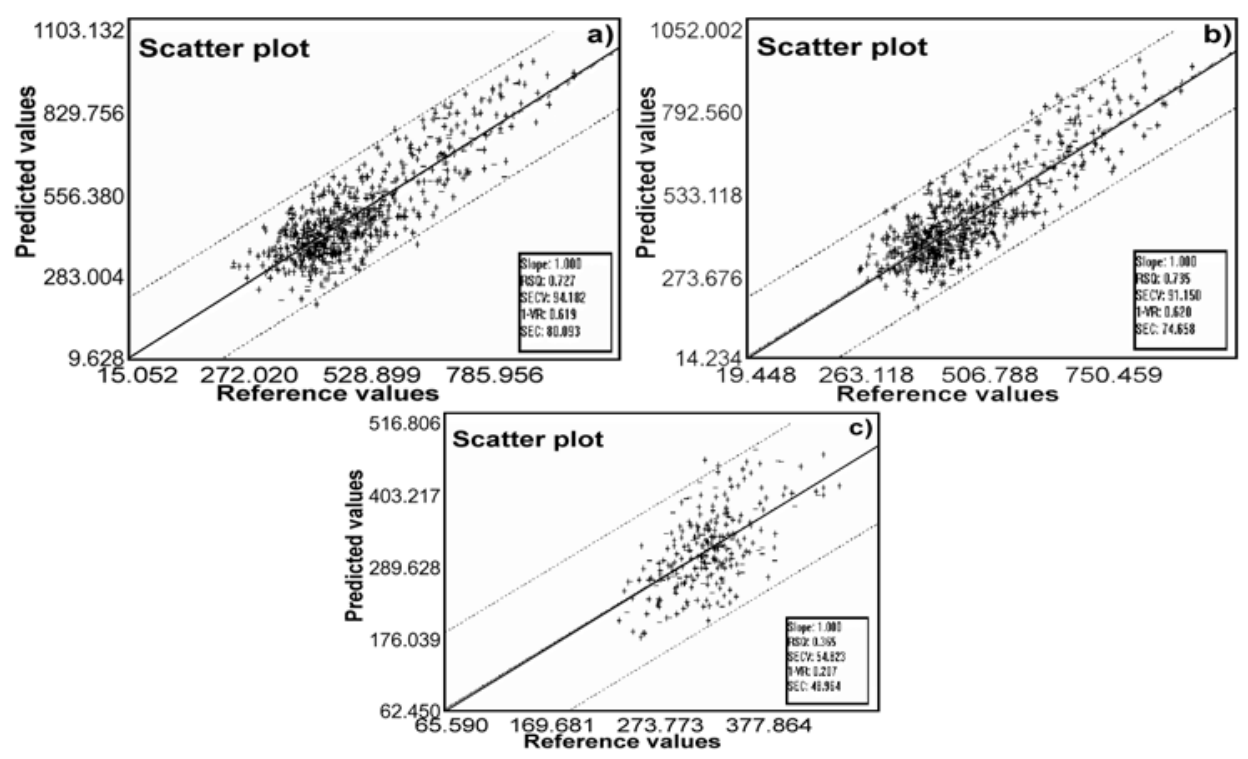

Figure 2: Reference vs. predicted values (a) Total tocopherol ( $\mathrm{mg} / \mathrm{kg}$ oil) (sum of the four isomers $\alpha, \beta, \gamma$ and $\delta$ ); (b) $\alpha$-tocopherol ( $\mathrm{mg} / \mathrm{kg}$ oil) and (c) Total phytosterols ( $\mathrm{mg} /$ $100 \mathrm{~g}$ oil) values for the calibration set.

In order to broaden the range representing the variability of the content in tocopherol, we propose to establish a larger calibration dataset and to use an appropriate mathematical treatment.

In conclusion, a selection for the tocopherol content based on NIRS information could be possible for plant breeding or allotment whereas it seems more difficult to determinate the phytosterol content by this method. Further investigations will be undertaken to improve the two prediction models, based on the above propositions.

\section{ACKNOWLEDGMENTS}

The authors thank Caussade Semences, Maïsadour Semences, Monsanto Dekalb, RAGT-R2N, Soltis, Syngenta Seeds for providing field experiment sites and sunflower plant material. Financial support was provided by ASEDIS-SO, ONIDOL (French oil seeds organization) and Midi-Pyrénées Region. We also thank Cognis-France for their technical support. 


\title{
REFERENCES
}

Ayerdi Gotor, A., Berger, M., Labalette, F., Centis, S., Daydé, J., 2006. Etude de la variation des teneurs et compositions des composés mineurs dans l'huile de tournesol au cours du développement du capitule: Partie I -tocophérols. OCL. In press.

Ballerini, D., 2006. Les biocarburants: Eat de lieux, perspectives et enjeux du dévéloppement. pp. 370.

Beardsell, D., Francis, J., Ridley, D. and Robards, K., 2002. Health promoting constituents in plant derived edible oils. J. Food Lipids 9: 1-34.

Bramley, P.M., Elmafda, I., Kafatos, A., Kelly, F.J., Manios, Y., 2000. Vitamin E. J. Sci. Food Agr. 80: 913-938.

De Caro, D. and Cecutti, C., 2005. Lubrifiants et environnement. OCL. 12: 279-284.

Dutta, P. and Normen, L., 1998. Capillary column gas- liquid chromatographic separation of delta 5-unsaturated and saturated phytosterol. J. Chromatogr. A. 816: 177-184.

Hofius, D. and Sonnewald, U., 2003. Vitamin E biosynthesis: Biochemistry meets cell biology. Trends Plant Sci. 8: 6-8.

Ling, W.H. and Jones, P.J., 1995. Dietary phytosterols: A review of metabolim, benefits and side effects. Life Sci. 57: 195-206.

Moschner, C. and Biskupek-Korel, B., 2006. Estimating the content of free fatty acids in higholeic sunflower by near-infrared spectroscopy. Eur. J. Lipid Sci. Technol. 108:

Normen, L., Dutta, P., Lia, A. and Andersson, H., 2000. Soy sterol esters and beta-sitostanol ester as inhibitors of cholesterol absorption in human small bowel. Am. J. Clin. Nutr. 71: 908-913

Perez-Vich, B., Velasco, L. and Fernandez-Martinez, J., 1998. Determination of seed oil content and fatty acid composition in sunflower through the analysis of intact seeds, husked seeds, meal and oil by near-infrared reflectance spectroscopy. J. Am. Oil Chem. Soc. 75: 547-555.

Tasinat, A., Boscoboinik, D., Bartoli, G., Maroni, P., 1995. D-alpha-tocopherol inhibition of vascular smooth muscle cell proliferation occurs at physiological concentrations correlates with protein kinase $\mathrm{c}$ inhibition, and is independent of its antioxidants activities. Proc. Natl. Acad. Sci. USA. 92: 12190-12194.

Trautwein, E.A., Duchateau, G., Lin, Y.G., Mel'nikov, S.M., Molhuizen, H.O.F., 2003. Proposed mechanisms of cholesterol-lowering action of plant sterols. Eur. J. Lipid Sci. Technol. 105: 171-185.

Vlahakis, C. and Hazebroek, J., 2000. Phytosterol accumulation in canola, sunflower, and soybean oils: Effects of genetics, planting location, and temperature. J. Am. Oil. Chem. Soc. 77: 49-53.

\section{DETERMINACIÓN DE LA CANTIDAD DE MICROCOMPONENTES DE GIRASOL POR MEDIO DE ESPECTROMETRÍA INFRARROJA DE REFLECTANCIA CERCANA (NIRS)}

\author{
RESUMEN
}

Los métodos rápidos y baratos de caracterización de girasol antes de seleccionarlo, son necesarios como en los programas de selección, tanto en la industria de procesamiento. La espectrometría infrarroja de reflectancia cercana (NIRS) tiene amplio uso para la clasificación de lotes de semilla de girasol según el contenido de ácidos grasos. Esta investigación sugiere la ampliación del uso potencial de NIRS para la cuantificación del contenido de tocoferol y fitosterol en girasol. Alrededor de 800 muestras de semilla de girasol molida, fue escaneada por el NIRS en intervalos de $2 \mathrm{~nm}$ en el rango de 400 do 250 nm. En cada una de las muestras, de forma estándar fueron medidos el contenido de tocoferol y fitosterol. El contenido total de tocoferol fue obtenido por la cromatografía líquida de altas propiedades (HPLC), con ayuda del detector flu- 
orescente, y el contenido total de fitosterol fue calificado como cromatográfico gaseoso (GC). Para tocoferol, el rango de datos de calibración vacilaba entre 190 y $1280 \mathrm{mg} \mathrm{kg}^{-1}$ de aceite (valor medio alrededor de $615 \pm 165 \mathrm{mg} \mathrm{kg}^{-1} \mathrm{de}$ aceite). Para el contenido de fitosterol, el rango de calibración vacilaba entre

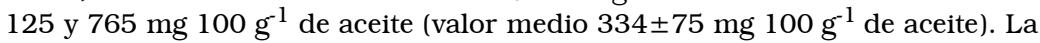
calibración NIRS mostró una correlación relativamente buena $\left(R^{2}=0,62\right)$ entre los valores establecidos sobre la base de NIRS y los valores reales para el contenido de tocoferol, pero la correlación para el contenido total de fitosterol era baja $\left(R^{2}=0,21\right)$. Estos resultados indican que la espectrometría NIR puede ser útil para la clasificación de lotes de semilla con el alto y bajo contenido de tocoferol, independientemente del posible aumento de precisión incluyendo mayor número de datos en la calibración NIRS para tocoferoles. Opuesto a ello, la determinación del contenido de fitosterol por medio de NIRS, requiere investigaciones adicionales. En este trabajo fue examinado sólo un método de calibración matemática, mientras que los demás métodos se están investigando todavía.

\section{DÉTERMINER LA gUANTITÉ DE MICROCOMPOSANTS DU TOURNESOL PAR LA SPECTROMÉTRIE DU PROCHE INFRAROUGE (SPIR)}

\section{RÉSUMÉ}

Les programmes de sélection des plantes et l'industrie alimentaire doivent tous les deux développer des méthodes économiques et rapides pour définir le tournesol avant son allotement. La spectrométrie du proche infrarouge est largement utilisée pour classer les lots selon le contenu d'acides gras. Cette étude propose une extension de l'usage potentiel de la SPIR pour la quantification du contenu de tocophérols et de phytostérols dans le tournesol. Environ 800 échantillons de graines de tournesol moulues ont été sondés par SPIR à intervalles de $2 \mathrm{~nm}$ sur une portée de 400 à $2500 \mathrm{~nm}$. Les contenus de tocophérols et de phytostérols ont été mesurés de manière standard dans chaque échantillon. Le contenu total de tocophérols a été obtenu par chromatographie liquide de grande performance (HLP) avec l'aide de détecteurs de fluorescence tandis que le contenu total de phytostérols a été obtenu par chromatographie gazeuse (GC). Pour le tocophérol, la portée du calibrage allait de 190 à $1280 \mathrm{mg} \mathrm{kg}^{1}$ d'huile (valeur moyenne $334 \pm 165 \mathrm{mg} \mathrm{kg}^{-1}$ d'huile) tandis que pour le contenu de phytostérols, la portée du calibrage allait de 125 à $765 \mathrm{mg} 100 \mathrm{~g}^{1}$ d'huile (valeur moyenne de $334 \pm 75 \mathrm{mg} \cdot 100 \mathrm{~g} \mathrm{~g}^{-1} \mathrm{~d}^{\prime}$ huile). Le calibrage SPIR a montré une corrélation relativement bonne $\left(R^{2}=0,62\right)$ entre les valeurs prévues par le SPIR et les valeurs réelles pour le contenu total de tocophérols mais une faible corrélation pour le contenu total de phytostérols $\left(\mathrm{R}^{2}=0,21\right)$. Ces résultats indiquent que la spectrométrie SPIR pourrait être utile pour classer des lots ayant un grand ou un faible contenu de tocophérols malgré une amélioration possible du calibrage par inclusion d'un plus grand nombre de données dans le calibrage de tocophérols SPIR. Au contraire, il faudrait des recherches supplémentaires pour déterminer le contenu de phytostérols par NIRS. Cette analyse n'a testé qu'une méthode de calibrage mathématique, les autres méthodes sont encore à l'étude. 